\title{
The Place of Art in Parlance of Environment and Human Health
}

\author{
Olawuni, P.O
}

Department of Urban \& Regional Planning Obafemi Awolowo University lle-Ife

Aremu, P.S.O

Department of Fine and Applied Arts, Obafemi Awolowo University, Ile-Ife

Benson, E.I

Department of Urban \& Regional Planning Obafemi Awolowo University lle-Ife

\section{Doi:10.5901/mjss.2014.v5n20p2261}

\section{Abstract}

The ultimate of arts or art work is aesthetics enhancement. Aesthetic is a major determinant when considering a built up environment. It is also important to note that a serene and friendly environment is another determinant of people's good health. This paper looks at the work of arts in terms of all artistic creativities in homes and cities, and their relevance to the present day environmental beautification, which equally has direct attribute to human health. An examination of artistic work and decorative devices right from individual homes (where available) is made. This was extended to the entire city in attempt to determine the aesthetic quality added to the environmental landscape. The contribution of aesthetic and good planning to the health of people was discussed. It was also pointed out that good art work constitutes aesthetic, and if well planned and articulated make a pleasant environment which in turn had a positive attribute to improved human health. It was therefore concluded that for a person to enjoy a complete good health, he/she needs beatified or aesthetic supportive environment. "It is a common feeling that most urban places are less than satisfactory - uncomfortable, ugly, or dull - as if they were being measured on some absolute scale. Only fragments of Settled world are generally excepted from this dismal view: an affluent suburb, a fine park, a historic town, the vital centre of some great city, an old farming region. If we could be articulate about why we feel that way, we might be prepared to make effective changes" (Lynch, 1981, p.1)

\section{Introduction}

Since enriched visual environment brings emotional fulfilment, the shaping and conservation of the built or the natural environment involves a very diverse range of professional skills. The town planning profession itself was formed from three constituent disciplines; architecture, surveying and civil engineering, including other accepted members from a wider range of backgrounds.

Although, art is not generally regarded as an essential part of a planner's eclectic outlook, but this paper argues that fine art may actually be relevant to environmental and planning practice. The work of various artists may be positively useful in identifying those features of environmental aesthetics that have impact on human health.

This paper endeavours to propose that a key purpose of environmental action in whatever sphere is the creation of a better visual environment, because people generally feel that authorities, planners, architects, builders and politicians at all levels have neglected environmental aesthetics and beauty, creating unpleasant, ugly, hostile, unfamiliar, unfriendly and unhealthy environments. For instance, most schools, hospitals, workplaces, traffic-areas, large housing estates, and many public and semi-public spaces are generally experiencing aesthetically deprived exterior and interior design, and lacking maintenance and care. It is worth noting that visual pleasure and stimulus is a basic human need. Visual poverty may be a less urgent preoccupation than mere material concerns. But the absence of visual excitement in the environment that forms the setting for people's lives is still a reason for lack of fulfilment. Art could provide pointer to the improvement of the visual quality of the environment.

Debates and works on how the quality of environmental aesthetics could be improved is however rare, therefore, this paper concerns itself with the broader use of art as a key to the visual environment and as a source of clues as to how the environment may be better made to enrich our visual lives and enhance our well-being. 


\section{Aesthetic City and Art}

People respond differently to the aesthetic qualities of cities, according to their personality, stage in life, socio-economic status and cultural background. Their responses involve both sensory (main visual) and intellectual factors (such as theoretical constructs of what constitutes an ideal city, and symbolic associations with culture) Lang (1998).

Increasingly, city authorities see public art as integral to their cities' cultural enhancement and renewal strategies, which are linked in turn to economic enhancement and peoples' well being. In some cities, public space may be a work of art: an example is, the boulevards of Paris. In addition, public space can as well be a container for work of art which will provide an aesthetic friendly environment.

The aesthetic appreciation of cities extends beyond public space. Worpole (2000) finds that beautiful and successfully articulated buildings (especially public buildings) are themselves visitor attractions that can generate widespread benefits. Another study for CABE by Carmona et al (2001a) finds: "Good urban (and architectural) design particularly well-designed public spaces - help to boost city pride." The same study observes that in some circumstances, while social value can be diminished by poorly designed public spaces, good urban design and art work will enhance social inclusiveness by reducing the need for high-profile security arrangements.

However, the symbiotic relationship between the public realm, and the many activities and idea that constitute public life, is as pointed out by Carr et al 1992. He noted that, "public space design and management has a cultural mission. Our parks and plazas and main streets can be precious social binders which help create and sustain a coherent and inclusive public culture".

\section{Green Spaces}

There is evidence that green spaces, which tend to reduce density, are valuable to people's health (Stone and Rodgers, 2001) and quality of life (including for recreation for children), and for conserving local biodiversity (de Vries et al, 2003; Bentley,1999; Sallis,et al, 1998). However, it is not clear how much green space needs to be conserved inside the city, to provide optimal green space for the urban area as a whole. Iconic green spaces such as Hagley Park in Christchurch, The /domain in Auckland, or Central Park in New York are clearly valuable in a local sense. This is indicated by property prices around such parks, and by local usage (Committee on Physical Activity, Health, Transportation and Land Use, (2005). But urban design that incorporates significant swathes of green space can have the effect of lowering densities and causing 'leapfrog' development in new peripheral suburbs. This irreversibly changes the nature of rural areas on the periphery and makes them less accessible to many in the city Landry, 2004; Hill Young Cooper Ltd. ). It also raises the costs of doing business in the urban area, generates more traffic, and lowers the environmental quality of the wider urban area. (Ewing, 1997).

There must always be some degree of trade-off between density and city greenery. The Urban Task Force in the United Kingdom and the US Environmental Protection Agency, among others, suggest a way through this conundrum. This is the polycentric urban form (or "cluster zoning") with high-density areas ("pyramids of intensification") interspersed with green wedges or area. (Urban Design Task Force (UK), 1999).

Viewed at a broader scale, this type of compact, clustered development is also likely to reduce disruption and fragmentation of habit, and preserve large areas in highly valued parks and open spaces. (United State Environmental Protection Agency, 2001; Ewing, 1997), but can have adverse effect on health and well being.

\section{Fine Art and the Environment}

Three aspects of the relevance of fine art to environmental and human health psychic will be examined. All, to some extent have parallels in the analysis of townscape by writers such as Gordon Cullen and Kevin Lynch and earlier by such analysts as Camillo Sitte. Specific links will be made with Cullen's Townscape. The first aspect is the representation of three-dimensional space; the second, the concern with surface texture; and the third the importance of light and colour in the visual environment with their relevance to human health. The choice of examples is subjective and does not attempt to show that all art has environmental relevance or that the chosen artists alone are of interest.

\section{Space and Perspective}

The portrayal of three-dimensional space on the flat surface of a picture has been a preoccupation of artists since the $15^{\text {th }}$ century and, before that, in classical antiquity. The theory and development of perspective in art is a complex subject 
which is beyond the scope of this paper. But it is worth quoting some examples which show that the concern of artists for spatial representation has much in common with the interest of Cullen and other townscape analysts in identifying the visually pleasing elements in our intuitive experience of towns and the broader environment.

The development of a perspective which might be perceived as 'natural' (although devised using a geometrical mode) was promoted by Brunelleschi in experiments at the Florence Baptistery in the early years of the 15thcentury. Brunelleschi's theories were put into practice by his friend Masaccio in his Trinity of 1427 (in the Church of Santa Maria Novella in Florence). The fresco gives the viewer the illusion of looking into a chamber in which the figures are set on a series of planes behind the flat surface of the wall, thereby creating a pleasing view.

In the same period paolo Uccello developed a very formal system of perspective in his frescoes and paintings on wood, most remarkably in A Hunt in a forest (Ashmolean Museum, Oxford). This painting depicts hunters and hounds in a dark forest, the figures converging to a central point in the depth of the woodland. The lines of the perspective 'box' are defined by the tree trunks and the figures themselves.

The effect of perspective in a two-dimensional painting is not the only way in which artists have sought to express the properties of space. Much of the work of the contemporary sculptor Richard Long takes the form of descriptions, in maps, photographs, and words, of heroically long walks and of impromptu sculpture made with materials found along the way. While these works explore the extensive space of entire geographical regions and countries, Long's gallery sculpture invites the viewer to concentrate on the qualities of the natural materials used and the ways in which the sculpture reflect and change the spaces in which they are set. A powerful example of Long's ability to give drama to an interior space was the Halifax Circle displayed in the south Transept of Lincoln Cathedral in 1990 as part of a city-wide exhibition called the Journey. Placed under the rose window it echoed the shape of the window on a different plane and gave tension to the rectilinear space of the transept itself. It then means that by the time one's mind is pe-occupied by when viewing these three dimensional object and serene environment, many other things bordering the mind would have disappeared. And when the mind is free, their will be peace of mind and sigh of good health emanates.

\section{Texture}

Spatial analysis is one key aspect of Gordon Cullen's book but equally memorable are the grainy, obliquely lit photographs illustrating the texture and detailed quality of the urban environment. The visual quality of this close-up paper lies in its abstract nature.

Here too the preoccupations of environmental professionals are echoed by those of artists. The models of Boyle Family are reproductions in moulded fibreglass and paint of metre-square patches of ground surface chosen at random within particular localities or from around the world. Much of their work forms part of a long-term project called Journey to the Surface of the Earth. These objects are often unremarkable in themselves: They include fragments of cobbled streets, ploughed fields, deserts, beaches or garden paths. The fact that they are selected, taken out of their context and displayed in the incongruous setting of an art gallery invites the viewer to look at them in a different way. By extinction the street outside can become both visually richer and more important. Or the messiness of broken edges to tarmac, road markings, fragments of part-covered surface material, and litter (items which Boyle Family readily incorporate into their work) is more noticeable. Whether the accidental qualities of the ground surface are seen as a source of pleasure or distress, Boyle family's sculpture heighten awareness of them. They can also heighten the pleasure in seeing for example, the beautiful, nearly detailed, granite pavements of Berlin or the simplicity of the award-winning paving scheme in the Cathedral precinct in Glasgow.

Another sculptor, Goldsworthy regards the natural environment as a source for his own analysis of texture and pattern. His vision is a more romantic one than that of either Richard Long or Boyle Family. Goldsworthy makes delicate sculptures using materials like a rocks, twigs and flowers to produce works which may be almost, but not quite, natural. Much of his work is ephemeral, existing in permanent form only in photographs. By shifting only slightly from what may intuitively be accepted as a natural object, Goldsworthy challenges and enhances the viewer's perception of the natural world. Sir Ernst Gombrich draws attention to this phenomenon as part of his analysis of the psychology of representation in art and illusion:

We go to picture gallery, and when we leave it after some time, the familiar scene outside, the road and the bustle, often look transformed and transfigured. Having seen so many pictures in terms of the world we can now switch over and see the world in terms of pictures. (Gombrich, 1977, p. 258). 


\section{Light and Colour}

The importance of light in the photographs used by Gordon Cullen in Townscape has been mentioned. A key component of the perception of the environment is the abstract experience of light and shade and in more intimate contexts, has been a major preoccupation of artists throughout history and certainly through the nineteenth century. The impressionists inherited a long tradition: The Monet's series of painting of Grainstacks described below used colours and an approach to light similar to Turner's in Norham Castle of 1845-50 (Tate Gallery, London).

Monet's series of paintings of Grainstacks from 1889 to 1891 provide a particularly vibrant example of the representation of light by using shimmering colours. In one example of the Grainstack (Sunset; winter) Monet paints the snow in a pattern of pinks, lavenders and yellows, almost separating the colours of the spectrum. Monet's colours are not a visually 'accurate' account of the landscape but give a sensation of light which carries a more powerful visual impact than a purely objective representation.

In another development, Micheal Taylor (1997) describes lan Kirkwood is a contemporary artist based in Lincolnshire. He is known mainly within the art world and his art does not set out deliberately to be easy on the viewer: it may take several visits to an exhibition before Kirkwood's pure abstraction evokes a response. But his work begins with drawing the landscape and his cool abstract paintings distil the light and colour in the landscape to an abstract sensation. However, in line with Monet, the influence of colour is very significant on the peoples' mental, spiritual and physical wellbeing, especially at homes, work places and relaxation centres. For example eBay Guides (2006) illustrates the association and effects of seven (7) selected basic colour chakras, using the table below. These seven basic colours (red, orange, yellow, green, blue, indigo and violet) have psychical influence on users in different environmental settings. The associations and effects of these seven colours will be highlighted in tabular form as shown here:

\begin{tabular}{|c|c|c|}
\hline Colours & Associations & Effects \\
\hline Red & $\begin{array}{l}\text { Vitality, energy and } \\
\text { courage. }\end{array}$ & Stimulates, gives energy and self confidence \\
\hline Orange & $\begin{array}{l}\text { Happiness, independence } \\
\text { and confidence }\end{array}$ & $\begin{array}{l}\text { Energizes, stimulates the appetite and digestive system, removes inhibitions and } \\
\text { fosters sociability. }\end{array}$ \\
\hline Yellow & $\begin{array}{l}\text { Awareness, wisdom and } \\
\text { clarity }\end{array}$ & $\begin{array}{l}\text { Energizes, relieves depression, improves memory, increases awareness, perception } \\
\text { and understanding. }\end{array}$ \\
\hline Green & Balance, love and peace & $\begin{array}{l}\text { Soothing, relaxing mentally as well as physically, helps alleviate depression, } \\
\text { nervousness and anxiety, offers a sense of renewal, self-control and harmony. }\end{array}$ \\
\hline Blue & $\begin{array}{l}\text { Knowledge, relaxation and } \\
\text { health }\end{array}$ & $\begin{array}{l}\text { Calming, lowers blood pressure and decreases respiration. Ideal for sleep and over- } \\
\text { active children. Enhances communication and decision-making. }\end{array}$ \\
\hline Indigo & $\begin{array}{l}\text { Intuition, imagination and } \\
\text { understanding }\end{array}$ & $\begin{array}{l}\text { Strengthens intuition and imagination, and increases dream activity. Helps connect } \\
\text { us to our unconscious mind. }\end{array}$ \\
\hline Violet & $\begin{array}{l}\text { Creativity, wisdom and } \\
\text { inspiration }\end{array}$ & $\begin{array}{l}\text { Suppresses appetite, provides a peaceful environment, relieves tension, and is good } \\
\text { for migraines. Promotes inner strength, wisdom, kindness, artistic talent and } \\
\text { creativity. }\end{array}$ \\
\hline
\end{tabular}

Source: eBay Guide, (2006)

\section{A Practical Consideration}

There are several reasons why people's interest should be furthered than becoming mere town planners and environmental designers. Prominent among them is artistic training that should provide particular skills in visual observation and representation. This often results in responses to the environment familiarities to planners. This familiarity does not mean that artists' responses and works cannot inform planners' own view about towns, countryside and the processes of change but that their artistic knowledge should be enriched. A concern with the visual environment is central to planning, not a finishing-off of a process whose main purpose is dominated by the mechanics and economics of environmental change.

Another reason for openness towards the ideas of fine artists lies in the nature and history of planning as a liberal profession, inviting a number of constituent professions and absorbing influences from many more. Like the emerging constituent professions, planning is a hybrid with wide terms of reference, and of its very nature should be open to influences from any source which can help it in its task of producing better places.

The quotation from Kevin Lynch which opens this paper invites planners to articulate the difference between 
environments perceived as good and those thought to be bad and having influence on health. Lynch goes on in his book to set out his own idea as to how this can be done. This paper suggests that spatial analysis, the observation of texture, and the effect of light and colour, offer a coherent way to make these comparisons. It further submits that the trained and practised perception of artists can be an aid in educating planners' critical abilities: in helping planners and other built environment professionals to analyse why one environment is dreary or unsatisfying while another is stimulating and a pleasurable place to be in.

\section{Conclusions}

Although the historic link between the fine arts and design in the environment has been diminished by specialisation, art can still be a source of support in creating a better visual environment. This can be addressed by involving artists directly in the design of the environment. But this has not been the main focus of this paper. Rather the primary concern has been with the potential of art in sharpening visual awareness and identifying the good and bad features of the environment and the influence they have on human health. Most of us know intuitively what sort of environments we enjoy living in. Attention to the work of painters and sculptors can help us to recognise and articulate that we find comfortable and stimulating. Once we have found a way to codify those responses we have a consistent basis for action.

It is then suggested that, in order to secure a sustainable serene and aesthetically meaningful environment, which can have a significant effect on human health, input of planners alone are not enough. Other professionals, especially, the fine artists are very important and must not be overlooked. Fine art can thus be part of the equipment for good planning.

\section{References}

Bentley, I. (1999). Urban Transformation: power, People and Urban Design. London: Routledge.

Camagni, R., Gibelli, M. C., and Rigamonti, P. (2002). Urban Mobility and Urban Form: The social and environmental costs of different patterns of urban expansion. Ecological Economics, 40 (2), 199-206.

Carmona, M., de Magalheas, C., Edwards, M., Awuor, B., Aminossehe, S. (CABE) (2001 a). The Value of Urban Design: A research report commissioned by CABE and DETR to examine the value added by good urban design. London: Thomas Telford Publishing.

Carr, S., Francis, M., Rivlin, L., and Stone, A. (1992). Public Space. Cambridge: Cambridge University Press.

Cartes, I. (1997). Art in the urban landscape. Urban Design International, 2(4), 189-198.

Committee on Physical Activity, Health, Transportation and Land Use. (205). Report Summary: TRB Special Report 282: Does the build environment influence physical activity? Washington: Transportation Research Board (TRB) and Institution of medicine of the National Academics.

Cullen, G. (1971): The Concise Townscape (London, Architectural Press).

De Montfor University (1995): Artists at Work, (Exhibition catalogue) (Leiscester, De Montfort University).

de Vries, S., Verheij, R., Groenewegen, P., and Spreeuwenberg, P. (2003). Natural Environments - Healthy Environments? An exploratory analysis of the relationship between greenspace and health. Environment and Planning A, 35, 1717-1731.

eBay Guide, (2006): Art and Chakras to Enrich your Life, Environment and Health.

Ewing, R. (1997). Is Los Angeles-style Sprawl Desirable?, Journal of the American Planning Association, 63 (1) 107-126

Gombrich, E. H. (1977): Art and Illusion: A Study in the Psychology of pictorial Representation, $5^{\text {th }}$ edn (London, Phaidon).

Hill Young Cooper Ltd. (1997). ASPII: Strategic Evaluation Report. Auckland: Auckland Regional Council.

Landry, C. (2004). Riding the rapids: Urban life in an age of complexity. London: Building Futures (Royal Institute of British Architects, Commission for Architecture and the Built Environment).

Lang, J. (1994). Urban Design: The American Experience. New York: Van Nostrand Reinhold.

Leicester City Council (1993): The Quality of Leicester (Leicester, Leicester City Council; 2nd edn 1997).

Luther, M. and Gruehn, D. (2001), Putting a price on urban green spaces. Landscape Design, 303,23-25.

Lynch, K. (1996): Good City form (Cambridge, MA, MIT Press).

Maller, C., Townsend, M., Brown, P., St Leger, L. (2002). Healthy Parks, Healthy People. Victoria, Australia: Deakin University and Parts Victoria. Retrieved April 2005 from htt://www.parkweb.vicgov.au/resources/mhphp/pv1.pdf.

Micheal Taylor, (1997): Fine art and Good Planning. Planning Practice and Research, Vol.12. No.4.

Mossop, E., and Walton, P. (eds.), (2001). City Spaces: Art and Design Sydney: Craftsman House.

Roberts, M., and Erickson, B. (1996). Artful change: public art and city regeneration. Urban Design International, 1(2), 163-171.

Sallies, J., Bauman, A., and Pratt, M. (1998). Environmental and policy interventions to promote physical activity, American Journal of Preventive Medicine, 15(4), 379-397.

Stone, B., and Rodgers, M. (2001). Urban From and Thermal Efficiency: How the design of cities influences the urban heat island effect. Journal of the American Planning Association, 67 (2), 186-198.

USEPA. (2001), Our Built and National Environments: A Technical review of the interactions between land use, transportation, and 
environment quality. Washington: United States Environmental Protection Agency. (Publication No. EPA 231-R-01-002). Retrieved 16 December 2004 from http://www.epa.gov/dced/pdf/built.pdf.

Vandergrift, D., and Yoked, T. (2004). Obesity Rates, Income, and Suburban Sprawl: An analysis of US states. Health and Place, 10,221-229.

Wansborough, M., and Mageean, A. (2000). The role of Urban design in cultural regeneration. Journal of Urban Design, 5(2), $181-197$.

Wheeler, K. (1976): Experiencing townscape, Bulletin of Environmental Education, December.

Worpole, K. (2000). The Value of Architecture: Design, economy and the architectural imagination. London: Royal Institute of British Architects. Retrieved 7 February 2005 from http:/www.buildingfutures.org.uk/pdfs/pdffile_24.pdf. 